PENELITIAN

\title{
Perbandingan Efektivitas Antara Nebulisasi Lidokain dan Spray Lidokain untuk Mencegah Refleks Batuk pada Tindakan Bronkoskopi dengan General Anestesi
}

\section{Comparation of Effectiveness Between Lidocaine Nebulisation and Lidocaine to Prevent Reflexes of Cough in Bronchoscopy Under General Anesthesia}

\author{
Anna Erliana Oetarman, Edward Kusuma, Maulydia, Arie Utariani ${ }^{\bowtie}$ \\ Departemen Anestesi dan Terapi Intensif, Fakultas Kedokteran, Universitas Airlangga/RSUD \\ Dr.Soetomo Surabaya, Indonesia \\ ${ }^{\circledR}$ Korespondensi: arieutariani@ fk.unair.ac.id
}

\begin{abstract}
Background: Cough often occur during bronchoscopy. Cough make patient's discomfort and bringing difficulties for bronchoscopy that triggers a higher complication risk for examples intrabronchial bleeding, bronchospasm and pneumothorax. Local anesthesia lidocaine can be used to prevent cough in bronchoscopy.

Objective: To compare the effects between lidocaine nebulization $2 \%$ and lidocaine spray $10 \%$ to preventing the occurrence of cough in bronchoscopy under general anesthesia. Methods: The study was conducted on 20 patients aged between 18-65 years old with the physical status of the American Society of Anesthesiologist (ASA) I and II, who underwent bronchoscopy under general anesthesia using oral intubation. Patients were divided into 2 groups: group lidocaine spray $10 \%$ and group lidocaine nebulization $2 \%$ with same dose $2 \mathrm{mg} / \mathrm{kg}$. Vital signs (blood pressure, heart rate, oxygen saturation and breath frequency) and the depth of anesthesia with bispectral index (BIS) are measured during bronchoscopy. Both lidocaine spray and lidocaine nebulization are given before anesthesia. Then, the cough incidence and cough degree are monitorized during and after bronchoscopy. Analysis of the results used two methods, Mann Whitney and Wilcoxon test. Mann Whitney test with significance degree $p<0,05$ are used to compare the cough incidence in both groups during and two hours after bronchoscopy, while Wilcoxon test with significance degree $p<0,05$ are used to compare the cough degree before and during bronchoscopy in each group.

Results: There was significant difference in cough degree between before and after the administration of lidocaine spray nor lidocaine nebulization $(p<0,05)$. There was significant difference in cough degree between lidocaine spray and lidocaine nebulization $(p<0,05)$, where lidocaine nebulization caused lower cough degree than the lidocaine spray. No side effects were reported in this study.
\end{abstract}


Conclusion: Administration of lidocaine nebulisation 2\% more efective supresses cough than lidocaine spray $10 \%$ in bronchoscopy under general anesthesia.

Keywords: anesthesia; bronchoscope; cough; lidocaine; nebulisation

\begin{abstract}
ABSTRAK
Latar belakang: Batuk sering terjadi pada tindakan bronkoskopi. Batuk menyebabkan ketidaknyamanan pasien dan menimbulkan kesulitan pada pelaksanaan tindakan bronkoskopi sehingga dapat meningkatkan risiko komplikasi akibat bronkoskopi seperti perdarahan intrabronkial, bronchospasme, dan pneumothorax. Batuk pada tindakan bronkoskopi dapat dicegah dengan pemberian anestesi lokal lidokain.

Tujuan: Membandingkan efek nebulisasi lidokain $2 \%$ dibandingkan spray lidokain 10\% dalam mencegah kejadian batuk pada tindakan bronkoskopi dengan anestesi umum. Metode: Penelitian dilakukan pada 20 pasien usia 18-65 tahun dengan status fisik American Society of Anesthesiologist (ASA) I dan II yang menjalani tindakan bronkoskopi dengan anestesi umum menggunakan intubasi oral. Pasien dibagi 2 kelompok: kelompok spray lidokain $10 \%$ dan kelompok nebulisasi lidokain $2 \%$ dengan dosis lidokain yang sama yaitu $2 \mathrm{mg} / \mathrm{kgbb}$. Tanda vital (tekanan darah, laju jantung, saturasi oksigen serta frekuensi napas) dan kedalaman anestesi dengan bispectral index (BIS) diukur selama bronkoskopi. Spray lidokain dan nebulisasi lidokain diberikan sebelum pembiusan dilakukan. Kemudian dievaluasi kejadian batuk dan derajat batuk selama dan setelah tindakan bronkoskopi. Analisis hasil penelitian menggunakan dua metode yaitu uji Mann Whitney dan uji Wilcoxon. Uji Mann Whitney dengan derajat kemaknaan $p<0,05$ untuk membandingkan kejadian batuk pada kedua kelompok selama dan dua jam setelah bronkoskopi, sedangkan uji Wilcoxon dengan derajat kemaknaan $\mathrm{p}<0,05$ untuk membandingkan derajat batuk sebelum bronkoskopi dan selama bronkoskopi pada masing kelompok.
\end{abstract}

Hasil: Terdapat perbedaan bermakna derajat batuk antara sebelum dan sesudah pemberian spray lidokain maupun nebulisasi lidokain $(\mathrm{p}<0,05)$. Ada perbedaan bermakna derajat batuk antara kelompok spray lidokain dibandingkan nebulisasi lidokain $(\mathrm{p}<0,05)$, dimana nebulisasi lidokain menimbulkan derajat batuk lebih rendah dibandingkan spray lidokain. Tidak ada efek samping pada penelitian ini.

Kesimpulan: Pemberian nebulisasi lidokain 2\% lebih efektif menekan refleks batuk dibandingkan spray lidokain 10\% pada tindakan bronkoskopi dengan general anestesi.

Kata Kunci: anestesi; batuk; bronkoskopi; lidokain; nebulisasi 


\section{PENDAHULUAN}

Bronkoskopi adalah tindakan medis untuk melakukan pemeriksaan secara visual terhadap saluran pernapasan atas dan bawah dengan tujuan penegakan diagnosis maupun terapetik. ${ }^{1,2}$ Keluhan yang sering dialami pasien yang menjalani bronkoskopi adalah batuk. Batuk akibat bronkoskopi muncul akibat adanya trauma mekanik yang disebabkan bronchoscopee pada dinding saluran napas dan reaksi inflamasi di saluran pernapasan. Batuk dapat berlangsung selama hingga beberapa jam setelah bronkoskopi. $^{3}$ Lidokain memiliki kemampuan untuk mencegah batuk. Pemberiannya secara topikal pada jalan napas dapat dengan cara gel, semprot dan nebulisasi. Metode yang umumnya digunakan pada bronkoskopi adalah dengan pemberian lidokain dengan cara disemprotkan / spray lidokain. ${ }^{4}$ Berdasarkan penelitian yang dilakukan oleh Emmanuel Udezue menunjukkan nebulisasi lidokain didapatkan inhalasi lidokain menekan refleks batuk, dan penggunaannya aman untuk dilakukan pada bronkoskopi. ${ }^{5}$

\section{METODE}

Jenis penelitian merupakan analitik eksperimental dengan rancangan prepost test design. Sebanyak 20 pasien dibagi menjadi 2 kelompok yaitu kelompok spray lidokain dan nebulisasi lidokain. Kelompok spray lidokain mendapatkan lidokain $10 \% 2 \mathrm{mg} / \mathrm{kgbb}$ dan kelompok nebulisasi mendapatkan lidokain $2 \% \quad 2 \mathrm{mg} / \mathrm{kgbb}$, keduanya diberikan sebelum tindakan anestesi. Kedua kelompok mendapatkan general anestesi dengan teknik intubasi oral dengan agen induksi fentanyl 1,5-2 $\mathrm{mcg} / \mathrm{kgBB}$ iv dan propofol 2-4 mg/kgBB iv dengan agen rumatan anestesi propofol $100-200 \mathrm{mcg} / \mathrm{kgBB} / \mathrm{menit}$ iv dan $\mathrm{O}_{2} 100 \%$. Selama tindakan dilakukan monitoring tanda vital, bispectral index
(BIS) dan derajat batuk. Derajat batuk mengunakan kriteria Minogue dibagi menjadi skala 0 (tidak batuk), skala 1 (batuk ringan / batuk satu kali), skala 2 (batuk sedang / batuk terus menerus $<5$ detik), skala 3 (batuk berat / batuk terus menerus > 5 detik). ${ }^{6}$ Analisis statistik dilakukan dengan uji Mann Whitney dan Friedman dengan nilai signifikan $\mathrm{p}$ $<0.05$.

\section{HASIL}

Pada penelitian ini didapatkan karakteristik umum pasien pada kelompok spray lidokain dan nebulisasi lidokain tidak memiliki perbedaan yang bermakna secara statistik beredasarkan umur, body mass index (BMI), jenis kelamin, diagnosis, patient statue of american of anesthesiology (PS ASA) dan durasi bronkoskopi seperti yang tercantum pada Tabel 1.

Selain itu juga dilakukan perbandingan derajat batuk pre bronkoskopi antara kelompok spray lidokain dan nebulisasi lidokain yang dapat dilihat pada Tabel 2 . Derajat batuk pre bronkoskopi pada kedua kelompok spray lidokain dan nebulisasi lidokain tidak menunjukkan adanya perbedaan yang bermakna derajat batuk antara kedua kelompok ( $p>0.05$ ).

Perbandingan derajat batuk pada durante bronkoskopi pada menit ke-0, menit ke15 dan menit ke-30 pada pasien yang mendapatkan spray lidokain dengan nebulisasi lidokain dapat dilihat pada tabel dibawah ini Tabel 3.

Pada durante bronkoskopi didapatkan derajat batuk yang lebih rendah pada menit ke-0, menit ke-15 dan menit ke-30 pada kelompok nebulisasi lidokain dibandingkan kelompok spray lidokain $(\mathrm{p}<0.05)$. 
Perbandingan derajat batuk antara pre, durante dan post bronkoskopi pada masing-masing kelompok dilihat pada Tabel 4.

Pada perbandingan derajat batuk post tindakan bronkoskopi menujukkan nebulisasi lidokain tidak menunjukkan perbedaan derajat batuk dibandingkan spray lidokain $\quad(\mathrm{p}<0.05) . \quad$ Pada perbandingan derajat batuk berdasarkan waktu pengamatan pre, durante dan post pada kelompok spray lidokain ataupun nebulisasi lidokain sama-sama menujukkan penurunan derajat batuk pada durante dan post bronkoskopi dibandingkan pre bronkoskopi dengan nilai $\mathrm{p}<0.001(\mathrm{p}<0.05)$.

Tabel 1. Karaktersitik umum subjek penelitian

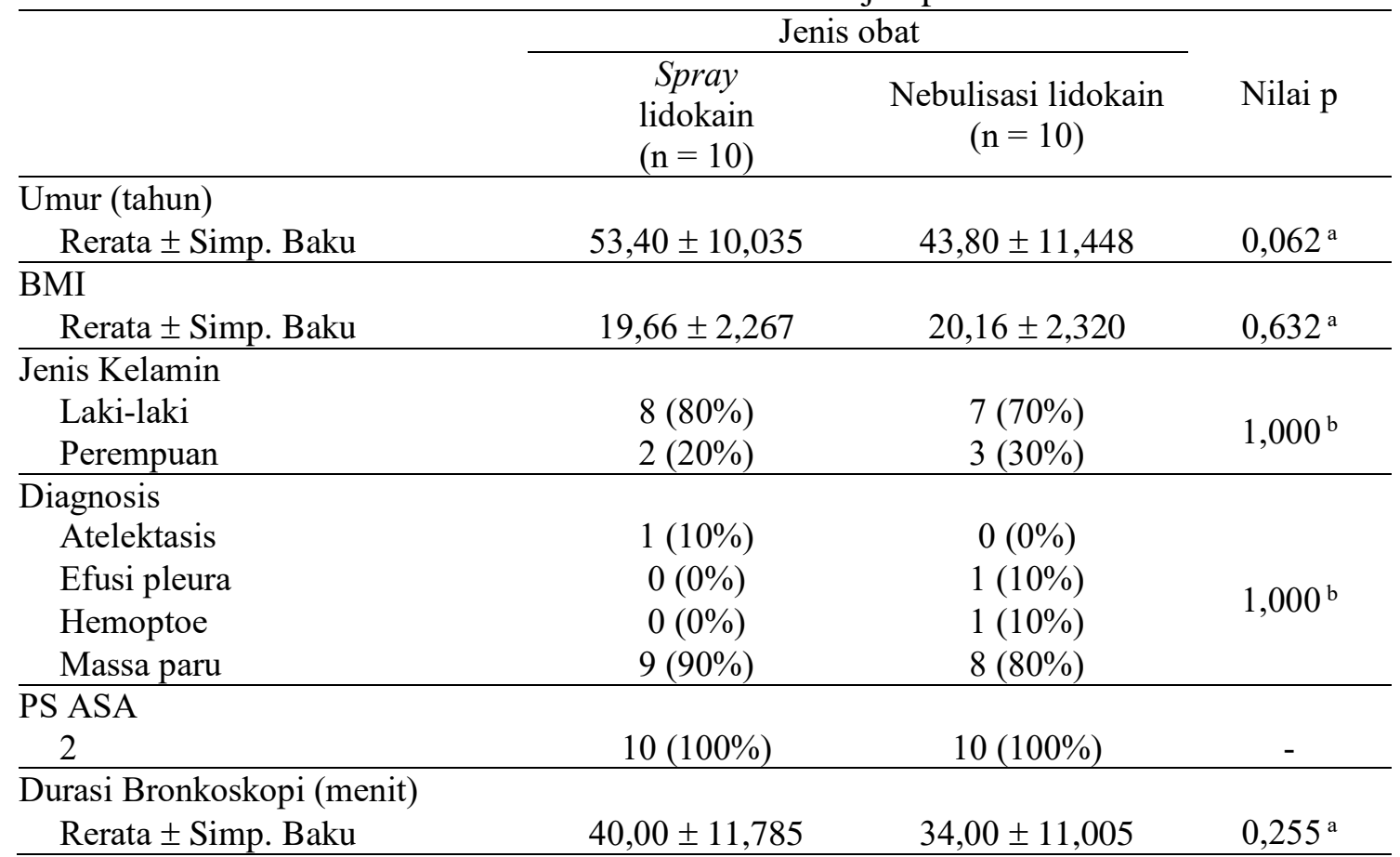

Keterangan: $\mathrm{a}=$ uji t 2 sampel bebas; $\mathrm{b}=$ uji Fisher's exact

Tabel 2. Derajat batuk pre bronkoskopi

\begin{tabular}{ccccc}
\hline \multirow{2}{*}{$\begin{array}{c}\text { Derajat batuk pre } \\
\text { bronkoskopi }\end{array}$} & \multicolumn{2}{c}{ Jenis obat } & \multirow{2}{*}{ Total } & Nilai p \\
\cline { 2 - 3 } Skray Lidokain & Nebulisasi Lidokain & & \\
\hline Skala 0 & $0(0 \%)$ & $0(0 \%)$ & $0(0 \%)$ & \\
Skala 1 & $1(10 \%)$ & $2(20 \%)$ & $3(15 \%)$ & 1,000 \\
Skala 2 & $8(80 \%)$ & $6(60 \%)$ & $14(70 \%)$ & \\
Skala 3 & $1(10 \%)$ & $2(20 \%)$ & $3(15 \%)$ & \\
\hline Total & $10(100 \%)$ & $10(100 \%)$ & $20(100 \%)$ & \\
\hline
\end{tabular}


Tabel 3. Derajat batuk durante bronkoskopi menit ke-0, 15 dan 30

\begin{tabular}{llllll}
\hline \multirow{2}{*}{ Durante op } & $\begin{array}{l}\text { Derajat } \\
\text { batuk }\end{array}$ & $\begin{array}{l}\text { Spray } \\
\text { lidokain }\end{array}$ & $\begin{array}{l}\text { Nebulisasi } \\
\text { lidokain }\end{array}$ & Total & Nilai p \\
\hline Menit ke-0 & Skala 0 & $2(20 \%)$ & $9(90 \%)$ & $11(55 \%)$ & \\
& Skala 1 & $2(20 \%)$ & $1(10 \%)$ & $3(15 \%)$ & 0,001 \\
& Skala 2 & $5(50 \%)$ & $0(0 \%)$ & $5(25 \%)$ & \\
& Skala 3 & $1(10 \%)$ & $0(0 \%)$ & $1(5 \%)$ & \\
\hline Menit ke-15 & Skala 0 & $0(0 \%)$ & $5(50 \%)$ & $5(25 \%)$ & \\
& Skala 1 & $1(10 \%)$ & $5(50 \%)$ & $6(30 \%)$ & $<0,001$ \\
& Skala 2 & $3(30 \%)$ & $0(0 \%)$ & $3(15 \%)$ & \\
& Skala 3 & $6(60 \%)$ & $0(0 \%)$ & $6(30 \%)$ & \\
\hline Menit ke-30 & Skala 0 & $0(0 \%)$ & $6(60 \%)$ & $6(30 \%)$ & \\
& Skala 1 & $0(0 \%)$ & $4(40 \%)$ & $4(20 \%)$ & \\
& Skala 2 & $6(60 \%)$ & $0(0 \%)$ & $6(30 \%)$ & \\
& Skala 3 & $4(40 \%)$ & $0(0 \%)$ & $4(20 \%)$ & \\
\hline
\end{tabular}

Tabel 4. Derajat batuk berdasarkan waktu pengamatan pre, durante dan post

\begin{tabular}{|c|c|c|c|c|c|}
\hline \multirow{2}{*}{$\begin{array}{l}\text { Jenis } \\
\text { Obat }\end{array}$} & \multirow{2}{*}{$\begin{array}{l}\text { Derajat } \\
\text { batuk }\end{array}$} & \multicolumn{3}{|c|}{ Waktu Pengamatan } & \multirow{2}{*}{$\begin{array}{l}\text { Nilai } p \\
\text { Uji Freidman }\end{array}$} \\
\hline & & Pre & Durante & Post & \\
\hline \multirow{4}{*}{ Spray lidokain } & Skala 0 & $0(0 \%)$ & $0(0 \%)$ & $2(20 \%)$ & \multirow{4}{*}{$<0,001$} \\
\hline & Skala 1 & $1(10 \%)$ & $0(0 \%)$ & $7(70 \%)$ & \\
\hline & Skala 2 & $8(80 \%)$ & $8(80 \%)$ & $1(10 \%)$ & \\
\hline & Skala 3 & $1(10 \%)$ & $2(20 \%)$ & $0(0 \%)$ & \\
\hline \multirow{4}{*}{$\begin{array}{l}\text { Nebulisasi } \\
\text { lidokain }\end{array}$} & Skala 0 & $0(0 \%)$ & $9(90 \%)$ & $9(90 \%)$ & \multirow{4}{*}{$<0,001$} \\
\hline & Skala 1 & $2(20 \%)$ & $1(10 \%)$ & $1(10 \%)$ & \\
\hline & Skala 2 & $6(60 \%)$ & $0(0 \%)$ & $0(0 \%)$ & \\
\hline & Skala 3 & $2(20 \%)$ & $0(0 \%)$ & $0(0 \%)$ & \\
\hline \multicolumn{2}{|c|}{$\begin{array}{l}\text { Nilai p } \\
\text { uji Mann Whitney }\end{array}$} & 1,000 & $<0,001$ & 0,002 & \\
\hline
\end{tabular}

\section{PEMBAHASAN}

Bronkoskopi bertujuan untuk menegakkan diagnosis sehingga dapat dilakukan terapi yang tepat pada pasien. ${ }^{7}$ Bronkoskopi terdiri dari rigid bronkoskopi dan flexible bronkoskopi. Pada penelitian ini menggunakan flexible bronkoskopi atau fiber-optik bronkoskopi. Flexible bronkoskopi dapat dilakukan dengan lokal anestesi, sedasi dan general anestesi. Teknik yang digunakan tergantung pada kondisi pasien, prosedur bronkoskopi yang dilakukan serta operator yang mengerjakan. General anestesi dengan teknik intubasi menjadi pilihan yang digunakan pada prosedur bronkoskopi pada penelitian ini. Kombinasi dengan anestesi lokal sering digunakan untuk meminimalkan risiko komplikasi dan rasa tidak nyaman selama maupun sesudah tindakan bronkoskopi. ${ }^{8}$

Pasien yang menjalani bronkoskopi sering mengeluhkan rasa tidak nyaman seperti batuk. Pada penelitian yang dilakukan oleh Takashi Hirose et al, 
sebanyak $86 \%$ pasien mengeluhkan terjadinya batuk pada tindakan bronkoskopi. ${ }^{9}$ Batuk tidak hanya menyebabkan ketidaknyamanan pasien yang signifikan, tetapi juga dapat menyebabkan ketindaknyamanan operator untuk melakukan tindakan yang dapat meningkatkan risiko komplikasi seperti perdarahan intrabronkial, bronchospasme dan pneumothorax. ${ }^{3}$ Ruptur bronkial dapat terjadi akibat batuk yang keras dan tidak berhenti selama manipulasi tindakan pada saat bronkoskopi. ${ }^{10}$

Batuk merupakan suatu refleks terhadap iritasi mekanis, kimia, atau inflamasi pada saluran pernapasan yang dimediasi oleh neuron sensorik dan diteruskan ke pusat batuk di batang otak. Batuk merupakan fungsi fisiologis untuk membersihkan saluran pernapasan dari bahan obstruktif atau iritasi dan melindungi saluran pernapasan dari zat berbahaya, namun pada kondisi tertentu batuk dapat menyebabkan gangguan bagi pasien saat beraktivitas maupun saat beristirahat. $^{11-13}$

Batuk pada bronkoskopi dikaitkan dengan adanya trauma mekanik pada saluran napas serta adanya reaksi inflamasi yang berat dan peningkatan produksi sekret pada saluran napas akibat bronkoskopi. Sejumlah besar pasien yang menjalani bronkoskopi menganggap bahwa batuk merupakan efek samping yang paling tidak diinginkan, batuk juga merupakan salah satu penyebab pasien tidak mau kembali untuk melakukan tindakan bronkoskopi berikutnya yang telah dijadwalkan. ${ }^{14}$

Pada penelitian ini karakteristik umum pasien pada kelompok spray lidokain dan nebulisasi lidokain tidak didapatkan perbedaan yang bermakna secara statistik. Walaupun berdasarkan nominal umur kelompok nebulisasi lidokain yaitu 43,80 \pm 11,448 lebih muda dibandingkan kelompok spray lidokain yaitu $53,40 \pm 10,035$. Pada orang tua lebih banyak terjadi batuk yang disebabkan oleh banyak faktor seperti penyakit parenkim paru-paru, GERD, obat ACEi dan komorbid lainnya. Meskipun jarang namun penyakit jantung seperti gagal jantung, endokarditis dan aritmia jantung dapat menyebabkan batuk kronis. ${ }^{15}$ Sehingga pada kelompok spray lidokain secara klinis memiliki kecenderungan untuk terjadinya derajat batuk lebih tinggi dibandingkan kelompok nebulisasi lidokain.

Derajat batuk pre bronkoskopi antara kelompok yang mendapatkan spray lidokain dengan nebulisasi lidokain secara statistik tidak memiliki perbedaan bermakna. Pada kelompok spray lidokain didapatkan durasi bronkoskopi yang lebih lama yaitu 40,00 $\pm 11,785$ dibandingkan kelompok nebulisasi lidokain yaitu $34,00 \pm 11,005$. Lamanya manipulasi jalan napas selama tindakan bronkoskopi akan meningkatkan komplikasi dari bronkoskopi yang berkisar antara $<0,1 \%$ hingga $11 \% .^{16}$ Semua pasien mengeluhkan adanya keluhan batuk yang didasari kelainan patologi paru sebelumnya, sebanyak 8090\% pasien pada penelitian ini di diagnosis dengan massa paru.

Salah satu cara mencegah atau menekan refleks batuk dapat dilakukan dengan pemberian obat anestetik lokal (lidokain). Lidokain merupakan obat anestesi lokal golongan amida. Lidokain mudah diserap dari tempat suntikan, dan dapat melewati sawar darah otak. Sekitar $70 \%$ (55-95\%) lidokain dalam plasma terikat protein. Metabolisme utama lidokain yaitu di retikulum endoplasma oleh enzim P450. ${ }^{17}$ 
Lidokain merupakan anestesi lokal yang paling sering digunakan untuk anestesi topical pada jalan napas. Lidokain yang diaplikasikan ke membran mukosa akan menghasilkan anestesi superfisial dalam waktu singkat. Onset terjadi dalam waktu 2-5 menit dengan lama kerja berkisar 3045 menit. Dosis aman maksimum 3-4 $\mathrm{mg} / \mathrm{kg}$, beberapa ahli merekomendasi hingga $6 \mathrm{mg} / \mathrm{kg} .{ }^{18,19}$

Lidokain secara reversibel memblokir gerbang saluran natrium pada akson saraf tepi sehingga menghambat terjadinya aksi potensial, sehingga menghambat konduksi saraf aferen dan eferen dari serabut saraf otonom seperti refleks batuk dengan memblokade refleks neurogenik di paru-paru dan blokade saraf jalur refleks vagal. Lidokain sebagai anti inflamasi dan spasmolitik sehingga sering digunakan sebagai terapi pada pasien asma. Lidokain menghambat fungsi sel-sel inflamasi seperti sel mast, sel Th2, makrofag, neutrofil, dan eosinofil. Penurunan refleks batuk juga disebabkan relaksasi pada otot polos dan efek spasmolitik lidokain dengan memblokade saluran kalsium yang mengakibatkan penurunan kalsium. ${ }^{5,9}$

Lidokain dapat diberikan dengan cara standar yaitu dengan spray atau dengan nebulisasi. Nebulisasi lidokain memfasilitasi distribusi anestesi lokal dari faring hingga ke saluran napas bawah, dan sering digunakan pada intubasi sadar / awake intubation. ${ }^{20}$ Pada penelitian ini pemberian spray lidokain diberikan dengan teknik menggunakan aplikator yang tersedia pada sediaan lidokain spray $10 \%$ dengan dosis 2 $\mathrm{mg} / \mathrm{kgbb}$ secara langsung melalui oral ke rongga orofaring. Pada nebulisasi lidokain menggunakan masker nebulizer yang diberikan lidokain $2 \% 2 \mathrm{mg} / \mathrm{kgbb}$ selama 15 menit. Pada penelitian ini digunakan masker nebuliser penggunaan tunggal untuk menjaga keamanan pasien dari bahaya penularan infeksi. Pada kedua kelompok juga dilakukan general anestesi dengan intubasi oral dengan induksi menggunakan obat fentanyl dan propofol yang memiliki efek anestesi yang juga memiliki peran untuk mensupresi batuk, selama tindakan untuk mencegah pasien underanesthesia maka dilakukan monitoring kedalaman anestesi dengan BIS dan monitoring tanda vital.

Pada penilaian batuk durante bronkoskopi pada menit ke-0, menit ke15 dan menit ke-30 antara kelompok spray lidokain dan nebulisasi lidokain menunjukkan hasil terdapat perbedaan yang bermakna antar kedua kelompok. Pada kelompok nebulisasi lidokain didapatkan derajat batuk yang lebih rendah dibandingkan kelompok spray lidokain. Hal ini dapat dimungkinkan oleh karena pada kelompok nebulisasi lidokain, nebulisasi diberikan selama 15 menit dan setelahnya langsung dilakukan tindakan anestesi dengan fentanyl dan propofol yang dilanjutkan dengan tindakan bronkoskopi. Sedangkan pada kelompok spray lidokain, tindakan anestesi dilakukan 15 menit setelah tindakan spray lidokain diberikan sehingga dimungkinkan penurunan derajat batuk yang signifikan pada kelompok nebulisasi lidokain diakibatkan juga oleh onset dan masa kerja dari fentanyl dan propofol. Propofol memiliki onset dan durasi aksi yang cepat dengan efek sedasi, propofol dengan dosis tinggi menyebabkan depresi napas dan kehilangan tonus jalan napas. Fentanyl merupakan obat golongan opiod yang sangat membantu untuk melemahkan respons hemodinamik dan ketidaknyamanan selama prosedur bronkoskopi. Kombinasi propofol dan fentanyl dapat 
menghambat reflek jalan napas seperti batuk. ${ }^{21}$ Faktor lain yang mempengaruhi penyerapan mukosa dari saluran bronkial yaitu produksi dahak, aliran udara obstruksi, dan riwayat merokok. ${ }^{22}$

Pada perbandingan derajat batuk pre, durante dan post bronkoskopi pada pasien yang mendapatkan spray lidokain didapatkan perbedaan yang bermakna dengan pengujian pada tiga waktu pengamatan dengan menggunakan uji Friedman. Pemberian spray lidokain menunjukkan adanya perubahan derajat batuk yang lebih rendah pada post bronkoskopi yang dibandingkan dengan pre dan durante bronkoskopi. Hal ini dimungkinkan karena teknik pemberian spray lidokain melalui orofaring memberikan anestesi yang terbatas pada rongga oral hingga uvula yang diakibatkan penggunaan aplikator spray lidokain yang berbeda dibandingkan pada literatur sebelumnya yang menunjukkan pemberian spray lidokain memberikan derajat batuk yang lebih rendah dibandingkan pemberian nebulisasi lidokain. Pada penelitian yang dilakukan Emmanuel Udezue didapatkan nebulisasi lidokain efektif untuk menekan batuk dengan konsentrasi lidokain yang bervariasi $1 \%$ hingga $4 \% .^{5}$

Pada perbandingan derajat batuk pre, durante dan post bronkoskopi pada pasien yang mendapatkan nebulisasi lidokain menunjukkan terdapat perbedaan yang bermakna dimana nebulisasi lidokain menekan derajat batuk lebih rendah dibandingkan pemberian spray lidokain. Berbeda dengan penelitian Sahajal Dhooria et al yang membandingkan nebulisasi lidokain dan spray lidokain, kelompok spray lidokain didapatkan lebih baik dalam menekan batuk dibandingkan nebulisasi lidokain maupun kombinasi keduanya. ${ }^{23}$ Sedangkan penelitian yang dilakukan oleh D Keane dan W. McNicholas membandingkan nebulisasi lidokain 4\% dan spray lidokain 10\% didapatkan hasil nebulisasi lidokain memiliki tingkat kenyaman yang lebih tinggi dan memiliki kemampuan yang sama untuk mensupresi batuk. ${ }^{24}$ Pada penelitian Tim Peipho et al didapatkan bahwa pemberian lidokain $2 \%$ yang nebulisasi menunjukkan hasil yang lebih baik dibandingkan pemberian lidokain $2 \%$ standar dengan spray melalui bronchoscope $^{25}$ Pemberian lidokain melalui nebulisasi akan menyebabkan penyebaran lidokain secara luas dalam bentuk aerosol di atas permukaan mukosa seluruh saluran pernapasan (hidung, mulut, faring, pita suara, trakea, dan bronkus). Namun seperti aerosol lainnya, proporsi obat lidokain yang mencapai tempat tujuan lebih kecil dan juga bervariabel. Nebulisasi lidokain merupakan prosedur yang aman, tidak mempengaruhi tanda vital, dan tidak menimbulkan komplikasi. Lidokain akan mencapai mukosa napas dan diabsorsi dari permukaan mukosa menyebabkan penurunan hipereaktif pada jalan napas dengan memblok saluran natrium pada mukosa sehingga tidak terjadi penjalaran impuls untuk diteruskan ke nervus vagus hingga ke pusat batuk, selain itu juga menurunkan pelepasan dari mediator inflamasi. $^{22}$

\section{KESIMPULAN}

Berdasarkan penelitian yang kami lakukan dapat disimpulkan bahwa pemberian nebulisasi lidokain pada penelitian ini menunjukkan derajat batuk yang lebih rendah dibandingkan pemberian spray lidokain pada tindakan bronkoskopi dengan general anestesi. Pemberian anestesi lokal baik spray lidokain maupun nebulisasi lidokain dapat menekan derajat batuk pada tindakan bronkoskopi. 


\section{DAFTAR PUSTAKA}

1. Manthous C, Tobin MJ. Flexible bronchoscopy (Airway Endoscopy). Am J Respir Crit Care Med. 2015;191(9):P7

2. Du Rand IA, Barber P V., Goldring J, Lewis RA, Mandal S, Munavvar $M$, et al. Summary of the British Thoracic Society Guidelines for advanced diagnostic and therapeutic flexible bronchoscopy in adults. Thorax. 2011;66(11):1014-5

3. Leiten EO, Martinsen EMH, Bakke PS, Eagan TML, Grønseth R. Complications and discomfort of bronchoscopy: a systematic review. Eur Clin Respir J. 2016;3(1):33324

4. Michael J. Morris, Herbert P. Kwon and Thomas B. Zanders. Monitoring, Sedation, and Anesthesia for Flexible Fiberoptic Bronchoscopy. Global Perspectives on Bronchoscopy. IntechOpen. 2012; 2 : 35-47

5. Udezue E. Lidocaine inhalation for cough suppression. Am J Emerg Med. 2001;19(3):206-7

6. Minogue SC, Ralph J, Lampa MJ. Laryngotracheal topicalization with lidocaine before intubation decreases the incidence of coughing on emergence from general anesthesia. Anesth Analg. 2004; 99:1253-7

7. José, R. J., Shaefi, S. and Navani, N. Sedation for flexible bronchoscopy: Current and emerging evidence. European Respiratory Review. 2013; 22(128):106-16.

8. Abdelmalak BB, Gildea TR, Doyle DJ. Anesthesia for Bronchoscopy. Current Pharmaceutical Design. 2012; 18:6314-24

9. Hirose, T. et al. Patient satisfaction with sedation for flexible bronchoscopy. Respirology. 2008; 13(5):722-7

10. Benedict, E. B. Rupture of the Bronchus from Bronchoscopy During a Paroxysm of Coughing. JAMA: The Journal of the American Medical Association. 1961; 178(5):509-10

11. Jung, S. Y., Park, H. Bin and Kim, J. D. The effect of a subhypnotic dose of propofol for the prevention of coughing in adults during emergence from anesthesia with sevoflurane and remifentanil', Korean Journal of Anesthesiology. 2014; 66(2):120-6

12. Shelly C. AARC Clinical practice guideline. Bronchoscopy assisting revision \& update. Respiratory Care. 2007; 52(1):72-80

13. Padma L. Current drugs for the treatment of dry cough. Assoc Physicians India. 2013; 61:9-13

14. Ling, I. T. et al. Posture influences patient cough rate, sedative requirement and comfort during bronchoscopy: An observational cohort study. Cough. 2011; 7(1):9.

15. Song, W. J. et al. Chronic cough in the elderly. Pulmonary Pharmacology and Therapeutics. 2019; 56(3):63-8

16. Asaad A, Clum S, Rumbak M. Fiberoptic Bronchoscopy Complications. J Respir Med Lung Dis. 2017; 2(4):1025

17. Stoelting, K \& Hiller, C. Pharmacology \& Physiology in Anesthetic Practice. Lippincott Williams \& Wilkins, Philadelphia, 2006

18. Pani N, Kumar Rath S. Regional \& topical anaesthesia of upper airways. Indian journal of anaesthesia. 2009; 53(6):641-8 
19. Kirkpatrick, M. B. Lidocaine topical anesthesia for flexible bronchoscopy. Chest. 1989; 96(5):965-7

20. Manish Khandelwal, Varun Kumar Saini, Sandeep Kothari, Gaurav Sharma. Role of Lignocaine Nebulization as an Adjunct to Airway Blocks for Awake Fiber-Optic Intubation: A Comparative Study. Anesth Essays Res. 2018; 12:735-41

21. Mondal S, Ghosh S, Bhattacharya S, Choudhury B, Mallick S, Prasad A. Comparison between dexmedetomidine and fentanyl on intubation conditions during awake fiberoptic bronchoscopy: A randomized double-blind prospective study. Journal of Anaesthesiology Clinical Pharmacology. 2015; 31(2):212-6

22. Wu, F.L, Razzaghi, A. and Souney, P. F. Seizure After Lidocaine for
Bronchoscopy: Case Report and Review of the Use of Lidocaine in Airway Anesthesia. Pharmacotherapy: The Journal of Human Pharmacology and Drug Therapy. 1993; 13(1):72-78

23. Dhooria, S. et al. A Randomized Trial of Nebulized Lignocaine, Lignocaine Spray, or Their Combination for Topical Anesthesia During Diagnostic Flexible Bronchoscopy. Chest. 2020; 157(1):198-204

24. Keane, D. and McNicholas, W. T. Comparison of nebulized and sprayed topical anaesthesia for fibreoptic bronchoscopy. European Respiratory Journal. 1992; 5(9):1123-5

25. Piepho, T. et al. Comparison of two different techniques of fibreoptic intubation', European Journal of Anaesthesiology. 2009; 26(4): 32832 